\title{
Environmental changes during the last millennium recorded in subfossil Cladocera, diatoms and sediment geochemistry from Lake EI Sol (Central Mexico)
}

\author{
Edyta ZAWISZA ${ }^{1,2, *}$, Estela CUNA ${ }^{2}$, Margarita CABALLERO $^{2}$, Ana Carolina RUIZ-FERNANDEZ ${ }^{3}$, \\ Krystyna SZEROCZYŃSKA ${ }^{1}$, Michał WOSZCZYK ${ }^{4}$ and Izabela ZAWISKA ${ }^{5}$ \\ 1 Polish Academy of Sciences, Institute of Geological Sciences, Twarda 51/55, 00-818 Warszawa, Poland \\ 2 Universidad Nacional Autónoma de México, Ciudad Universitaria, Instituto de Geofisica, D.F., Mexico \\ 3 Universidad Nacional Autónoma de México, Unidad Académica Mazatlán, Instituto de Ciencias del Mar, \\ Calz. J. Montes Camarena s/n, 82040 Mazatlán, Mexico \\ 4 Adam Mickiewicz University, Department of Quaternary Geology and Palaeogeography, Dzięgielowa 27, \\ 61-680 Poznań, Poland \\ 5 Polish Academy of Sciences, Institute of Geography and Spatial Organization, Twarda 51/55, 00-818 Warszawa, Poland
}

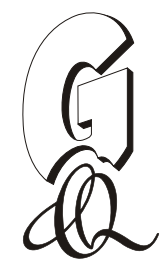

\begin{abstract}
Zawisza, E., Cuna, E., Caballero, M., Ruiz-Fernandez, A.C., Szeroczyńska, K., Woszczyk, M., Zawiska, I., 2017. Environmental changes during the last millennium recorded in subfossil Cladocera, diatoms and sediment geochemistry from Lake El Sol (Central Mexico). Geological Quarterly, 61 (1): 81-90, doi: 10.7306/gq.1311

High-altitude lakes, which are very sensitive ecosystems and respond rapidly to climatic changes, are one of the best targets for palaeolimnological studies. Here, we present the record of environmental changes over the last millennium that are recorded in the sediments of El Sol, a tropical, high-altitude, volcanic crater lake on the Nevado de Toluca, Central Mexico. Palaeolimnological reconstructions are based on subfossil Cladocera, diatoms, magnetic susceptibility and chemical analysis of the sediments. In general, Cladocera occurring in tropical regions, and especially at high altitude, have been studied very little. Our data indicate that in the sequence studied, the species diversity of subfossil Cladocera is very low. Only four species were recorded, and the assemblage is dominated by littoral species. Two Cladocera taxa, Alona manueli and llyocryptus, found at Lake El Sol are endemic. Cladocera, diatoms and the sediment chemistry show changes in Lake El So which are mostly related to climate. The most pronounced climatic signal was obtained for the early Little Ice Age (1350-1625 AD). This cold episode was expressed by a reduction in the frequency of zooplankton (individuals $/ \mathrm{cm}^{2} / \mathrm{yr}$ ) and diatoms (valves/g of dry sediment) and by changes in the organic carbon content in the sediment. Our results show that human activity was very limited throughout the study period. According to historical data the presence of humans at the lake shore was mostly occasional, usually for ceremonial and ritual purposes, and humans did not have an important influence on the lake ecosystem. Only one period was identified when human activity was important. This period corresponds to the introduction of fish into the lake at the beginning of the 20th century.
\end{abstract}

Key words: crater Nevado de Toluca, lake sediments, tropical alpine lake, palaeolimnology, last millennium.

\section{INTRODUCTION}

In an era of rapid and distinctive ecological and climatic changes, the effects of which are observed in modern times, reconstructions of past climatic changes have a special significance. Palaeolimnology and palaeoecology are one of the most important tools used for reconstruction and prediction of climate changes (Voigt, 2006; Bigler et al., 2007). However so far, palaeolimnological and palaeoecological analyses using sub-

\footnotetext{
* Corresponding author, e-mail: ezawisza@twarda.pan.pl
}

Received: January 25, 2016; accepted: April 27, 2016; first published online: September 12, 2016 fossil Cladocera, have been mainly conducted at high latitudes (Europe, Russia, Canada, and northern parts of the USA). Only a few studies on subfossil cladoceran fauna have been conducted in the southern hemisphere (e.g., Brazil, Chile, Uruguay, and New Zealand; Serafim et al., 2003; Iglesias et al., 2007; Coronel et al., 2007; Kotov et al., 2010; Kattel, 2010) and there is only one record from tropical North America (Mexico) (Zawisza et al., 2012; Cuna et al., 2014).

High-altitude lakes are particularly sensitive ecosystems as they respond rapidly to climatic changes. In these ecosystems, even very small differences in temperature between warm and cold periods can strongly affect water level, water chemistry, the length of the growing season, and the composition of aquatic plant and animal populations (Koining et al., 2002; Cuna et al., 2014). Additionally, high-altitude lakes are often considered to be pristine, which makes them suitable objects for studying past climatic and environmental changes (McCormack et al., 2009; 
Cuna et al., 2014). In addition the deposits of high-altitude lakes contain bio-indicator remains that reflect environmental changes, specifically the remains of Cladocera (Hofmann, 2000; Kamenik et al., 2007) and diatoms (Battarbee et al., 2002). Freshwater high-altitude tropical lakes are especially important for regional, global, past and future environmental reconstructions. Their sediments provide unique and valuable information about climate change at low latitudes, of which relatively little is known.

The main aim of this study was to trace ecological changes recorded in the sediments accumulated during the last millennium in the high-altitude, tropical Lake El Sol (Central Mexico). We present the results of a palaeolimnological study of this lake based on subfossil Cladocera, diatoms, magnetic susceptibility and chemical analyses of the sediments.

As with most alpine lakes, the lake is located above the treeline (4000 m a.s.I.) in a small catchment area, therefore we expect that these results should provide a "clear" ecological and climatic signal as high-altitude lakes are usually not affected by complex soil and vegetative responses to human activities in their catchments (Cuna et al., 2014).

\section{METHODS}

\section{STUDY AREA}

Lake El Sol (The Sun Lake) is located in Central Mexico, in the Nevado de Toluca volcano crater $\left(19^{\circ} 06^{\prime} 13^{\prime \prime} \mathrm{N}\right.$, $99^{\circ} 45^{\prime} 20^{\prime \prime}$ W, 4620 m a.s.I.), ca. 90 km SW from Mexico City (Fig. 1). The Nevado de Toluca is a dormant stratovolcano formed mainly by dacitic lava (García-Palomo et al., 2002). The crater of the volcano contains two lakes: EI Sol (bigger) and La Luna (smaller) that are separated from each other by the volcanic dome. According to Bloomfield and Valastro (1979), Armienta et al. (2000) and Arce et al. (2003) the Nevado de Toluca crater developed after a Plinian eruption dated to $10.5{ }^{14} \mathrm{C}$ ka BP (12 cal ka BP), and lakes located in the crater probably developed soon after this event. Another study (Macias et al., 1997; Macias, 2005) suggests that the volcano was last active ca. $3.3{ }^{14} \mathrm{C}$ ka BP (ca. $3.6 \mathrm{cal}$ ka BP), and the lakes formed after that time. However, recent research indicates that these lakes developed earlier than $4.5 \mathrm{cal}$ ka BP (Szeroczyńska et al., 2015).
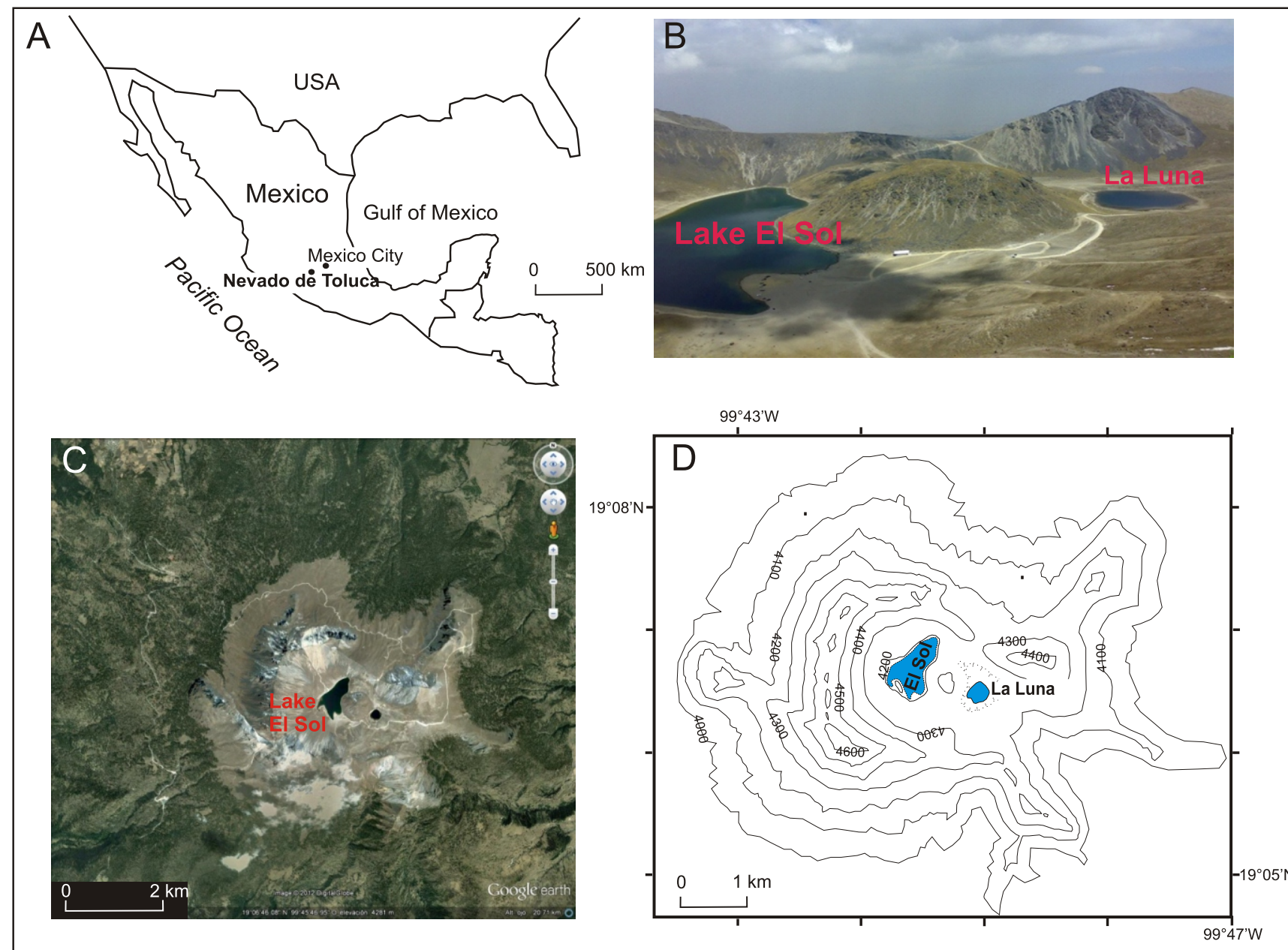

Fig. 1. Location of the study site, Lake El Sol

A - the location of the study site in the territory of Mexico; B - the photograph shows two lakes: (larger) El Sol and La Luna (smaller); Lake El Sol is located in the Nevado de Toluca crater and is separated from La Luna by the volcanic dome; C - a Google Earth image of the volcano Nevado de Toluca with the lakes EI Sol and La Luna in the top of the image; D - hypsometric map of the volcano Nevado de Toluca with the marked lakes El Sol and La Luna at altitude $4200 \mathrm{~m}$ a.s.I. 
The modern climate at the peak of Nevado de Toluca is cold, with a summer rainy season. The mean annual temperature is $4^{\circ} \mathrm{C}$, with a maximum in May $\left(19^{\circ} \mathrm{C}\right)$ and a minimum in January $\left(-9^{\circ} \mathrm{C}\right)$ (Mexican Meteorology Service). The mean annual precipitation is around $1.250 \mathrm{~mm}$. The vegetation surrounding the lake is mainly composed of several species of grasses. In the lower part of the mountain, below the tree line (4000 m a.s.I.), the vegetation consists of Pinus sp. and Abies sp. forests (Gonzalez, 1984). The Nevado de Toluca volcano has been a protected area since 1936 .

Lake El Sol is the largest lake in the crater, with a surface area of $200000 \mathrm{~m}^{2}$. The maximum depth of the lake is about $15 \mathrm{~m}$, its $\mathrm{pH}$ ranges between 5.5 and 7.2 and the electrical conductivity is between 19 and $60 \mu \mathrm{S} / \mathrm{cm}$. The lake is oligotrophic, warm polymictic and its water is very clear (light penetrates the entire water column to the bottom), and cold $\left(<10^{\circ} \mathrm{C}\right)$ (Caballero, 1996; Armienta et al., 2000; Alcocer et al., 2004; Dimas-Flores, 2005)

\section{MATERIALS AND METHODS}

A short $(45 \mathrm{~cm})$ sediment core was recovered in 2003 from the central and deepest part (11.5 m deep) of Lake EI Sol using a gravity corer. In this paper only the data from the top $27 \mathrm{~cm}$ will be presented. The core was sealed in a plastic tube and moved to the Paleolimnology Laboratory of the Geophysics Institute (UNAM, Mexico), where magnetic susceptibility (MS) measurements were taken at $2 \mathrm{~cm}$ intervals using a Bartington MS2C Core Sensor with a $10 \mathrm{~cm}$ internal diameter. Afterwards the core was split into longitudinal halves and its lithology was described. The core was then subsampled at $1 \mathrm{~cm}$ intervals for biological proxies, including subfossil Cladocera, diatoms, bulk geochemistry, and dating.

The chronology is based on ${ }^{210} \mathrm{~Pb}$ analysis and one AMS radiocarbon date from a depth of $27 \mathrm{~cm}$ (Fig. 2). The ${ }^{210} \mathrm{~Pb}$ analysis was conducted in the Laboratory of Isotopic Geochemistry and Geochronology, Institute of Marine Sciences and Limnology, UNAM, Mexico, and the sample for radiocarbon dating (pollen extract) was sent to a commercial laboratory (Beta Ana-
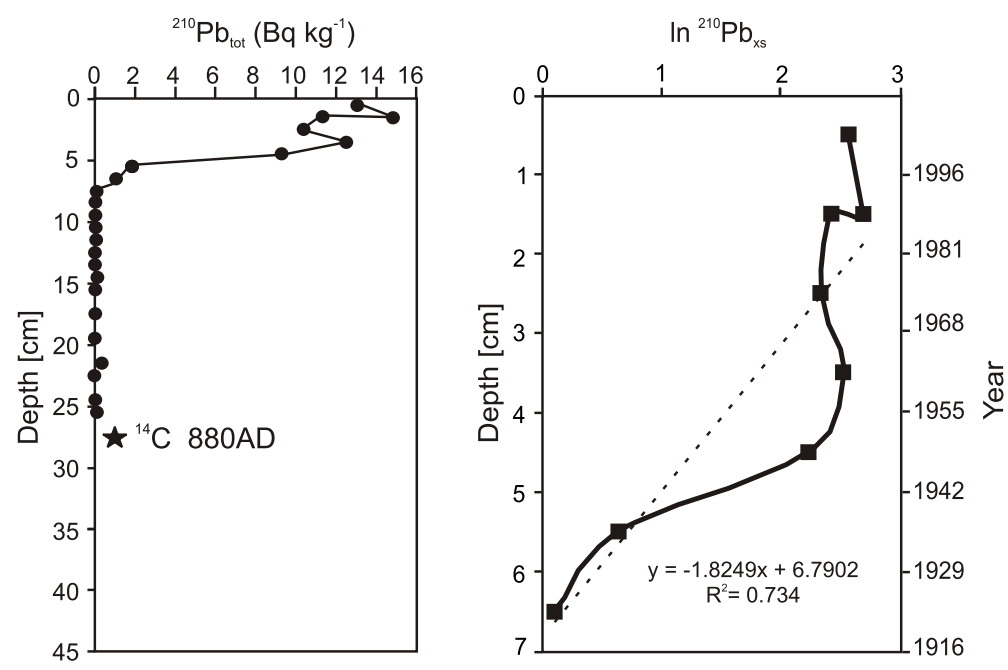

Fig. 2. Depth profile of ${ }^{210} \mathrm{~Pb}$ activities from a Lake El Sol sediment core

A - total ${ }^{210} \mathrm{~Pb}$ activities with asterisks indicating the $\mathrm{AMS}{ }^{14} \mathrm{C}$ age $(880+10 /-100 \mathrm{AD}) ; \mathbf{B}-$ logarithmic values of excess ${ }^{210} \mathrm{~Pb}$ activities and ${ }^{210} \mathrm{~Pb}$-derived sediment accumulation rates lytic, Florida, USA). ${ }^{210} \mathrm{~Pb}$ activities were obtained by measuring its daughter product, ${ }^{210} \mathrm{Po}$, assuming secular equilibrium between the two isotopes. Aliquots of $0.3 \mathrm{~g}$ of sediment were spiked with 209Po as a yield tracer, and they were digested in Savillex ${ }^{\mathrm{TM}}$ PFA containers in a 5:4:1 mixture of $\mathrm{HNO}_{3}+\mathrm{HCl}+$ $\mathrm{HF}$ on a hotplate $\left(180^{\circ} \mathrm{C}\right)$ overnight. The residue was converted to a chloride salt by repeated evaporation with $12 \mathrm{M} \mathrm{HCl}$ then dissolved in $0.5 \mathrm{M} \mathrm{HCl}$ with $2.5 \mathrm{~g}$ of $\mathrm{H}_{3} \mathrm{BO}_{4}$, and $0.2 \mathrm{~g}$ of ascorbic acid was added to the solution. Po isotopes were deposited on Ag discs at room temperature overnight on an orbital shaker, and the activity was measured by $\alpha$-spectrometry using ORTEC silicon surface barrier detectors coupled to a PC running Maestro ${ }^{\mathrm{TM}}$ data acquisition software. Blanks were run in parallel to correct for any contamination.

The preparation of sediments for subfossil Cladocera analysis was performed using the standard method (Frey, 1986; Szeroczyńska and Sarmaja-Korjonen, 2007). At least two slides were prepared (minimum 200 remains) from each sample $\left(1 \mathrm{~cm}^{3}\right.$ of sediment), containing all the Cladocera remains found: headshields, shells, postabdomens, postabdominal claws, and ephippia. The identification of Cladocera remains was based on Elias-Gutierrez et al. (1997, 2008), Cervantes-Martinez et al. (2000) and Sinev and Zawisza (2013).

Diatom samples were prepared by heating with $30 \% \mathrm{H}_{2} \mathrm{O}_{2}$ and $10 \% \mathrm{HCl}$ (Battarbee, 1986). They were mounted on slides using Naphrax® and subsequently a minimum of 500 valves were counted per sample using a light microscope with interdifferential phase contrasts (Olympus BX50 1000x) in order to determine valve concentration (valves per gram of dry sediment) and species relative abundance (\%). Diatom taxonomy largely followed Krammer and Lange-Bertalot (1986-1991, 1991). The results of both subfossil Cladocera and diatom analysis are presented on the percentage diagram (Fig. 3) using the C2 software (Juggins, 2005, 2007).

An elemental CNS analysis (Fig. 4) was performed on the samples from 1 to $24 \mathrm{~cm}$ depth using the VarioMax CNS analyser (Elementar). Each sample was analysed in two runs: one for total contents of carbon (TC), nitrogen (TN), sulphur (TS), and the second for the total organic C (TOC). For the TOC analysis, the powdered samples were acidified with $1 \mathrm{M} \mathrm{HCl}$ in silver foil to remove carbonates. When the reaction ceased, the samples were oven-dried at $105^{\circ} \mathrm{C}$ and loaded into the analyser. The total inorganic carbon (TIC), representing the content of carbonates, was calculated as the difference between TC and TOC (Fig. 4). The TOC/N ratio was calculated on a molar basis. Due to the small sample size, single measurements were performed, and their quality was controlled with reference materials (Sulfadiazine, Nutrients in soil and Metals in sewage sludge).

The cladoceran and diatom results were plotted on a relative abundance diagram using $C 2$ software (Juggins, 2005, 2007), and zones were distinguished using stratigraphically Constrained Incremental Sums of Squares (CONISS) using Euclidean distance (Grimm, 1987). Detrended correspondence analysis (DCA) was performed using the relative abundance of Cladocera and diatom species to evaluate species turnover through time and their association with environmental factors. This ordination technique was chosen as it avoids arch effects derived from linearity assumptions. The ordination units that are in this case standard deviation (SD) can be interpreted as an ecological turnover (Gauch, 1982). In order to explore results of chemical analysis of the sediments: TC, TN, TS, TOC and 


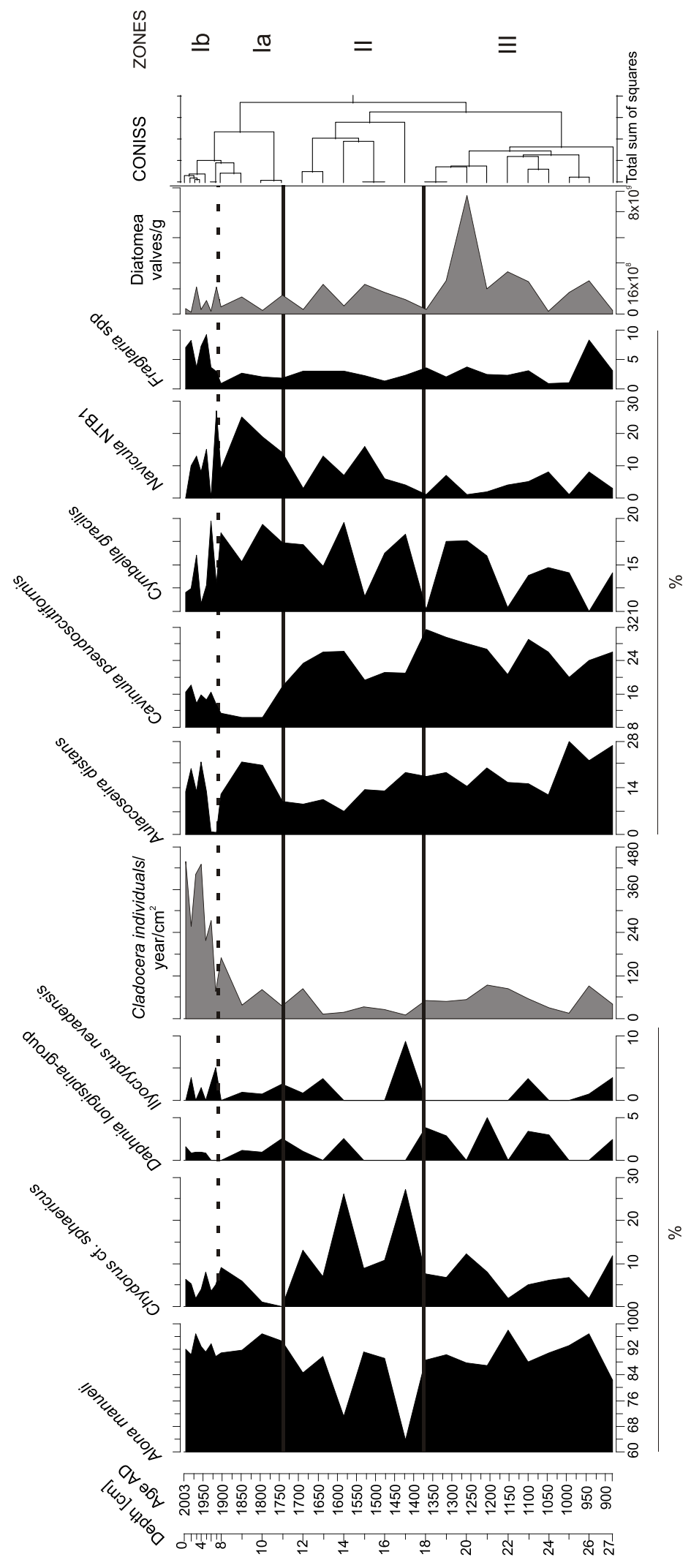

\begin{tabular}{|c|c|c|}
\hline $\begin{array}{c}\text { səu!! } \\
\text { fuəدunว }\end{array}$ & ә6ఈ әગ әામ! & $\begin{array}{l}\text { po!ıәd шuеM } \\
\text { ןелә!рәш }\end{array}$ \\
\hline
\end{tabular}

TIC and correspondence analysis (CA) was performed to evaluate changes through time. Correspondence analysis is a statistical visualization method for picturing the associations in the data set where the term correspondence denotes a "system of associations" between the elements. The goal is to have a global view of the data that is useful for interpretation. Both analyses were performed using R Project (Team, 2009) package vegan (Oksanen et al., 2012).

\section{RESULTS \\ LITHOLOGY}

The topmost $27 \mathrm{~cm}$ of the sediments of Lake El Sol were mostly composed of dark grey silty clay. Throughout the sediment sequence, we identified two silt bands of lighter colour (26.0-26.5 and 9.5-10 cm) and a wide black clayey band $(10-15 \mathrm{~cm})$. There were also three horizons of coarse sand and gravel $(7,11$ and $17 \mathrm{~cm})$.

The highest values of magnetic susceptibility (>8) were noted at depths $18-22 \mathrm{~cm}$, whereas the lowest values $(<8)$ occurred between 2 and $10 \mathrm{~cm}$ (Fig. 4). Generally, the values of magnetic susceptibility (MS) depend on the concentration of magnetic minerals in the sediments. Those minerals are usually transported into the lake from the catchment by precipitation and surface runoff. Due to the characteristics of the catchment and basin of this lake (poorly developed vegetation and soils), the magnetic susceptibility can be directly related to precipitation (Cuna et al., 2014).

\section{CHRONOLOGY}

The sediment chronology, based on excess ${ }^{210} \mathrm{~Pb}\left({ }^{210} \mathrm{~Pb}_{\mathrm{xs}}\right)$, was performed using the CFCS model (constant flux and constant sedimentation; Krishnaswami et al., 1971; Sanchez-Cabeza and Ruiz-Fernández, 2012), which assumes a constant ${ }^{210} \mathrm{~Pb}$ atmospheric flux and a constant sediment accumulation rate (SAR). The CFCS model can be applied to dating if a significant linear correlation is found between the logarithm of ${ }^{210} \mathrm{~Pb}_{\mathrm{xs}}$ activities and the depth of the sediment core. Significant linear correlations (t-Student's test, $P<0.05$ ) were found between the $\mathrm{In}{ }^{210} \mathrm{~Pb}_{\mathrm{ex}}$ and depth in the sediment core collected from Lake EI Sol (Fig. 2), thus confirming the validity of the CFCS hypotheses for the ${ }^{210} \mathrm{~Pb}$ chronology in the lake. The In ${ }^{210} \mathrm{~Pb}_{\text {ex }}$ depth profile obtained from Lake El Sol is presented in Figure 2, and the determined age of the sediments at $7 \mathrm{~cm}$ depth was $1916 \mathrm{AD}$. The lower part of 


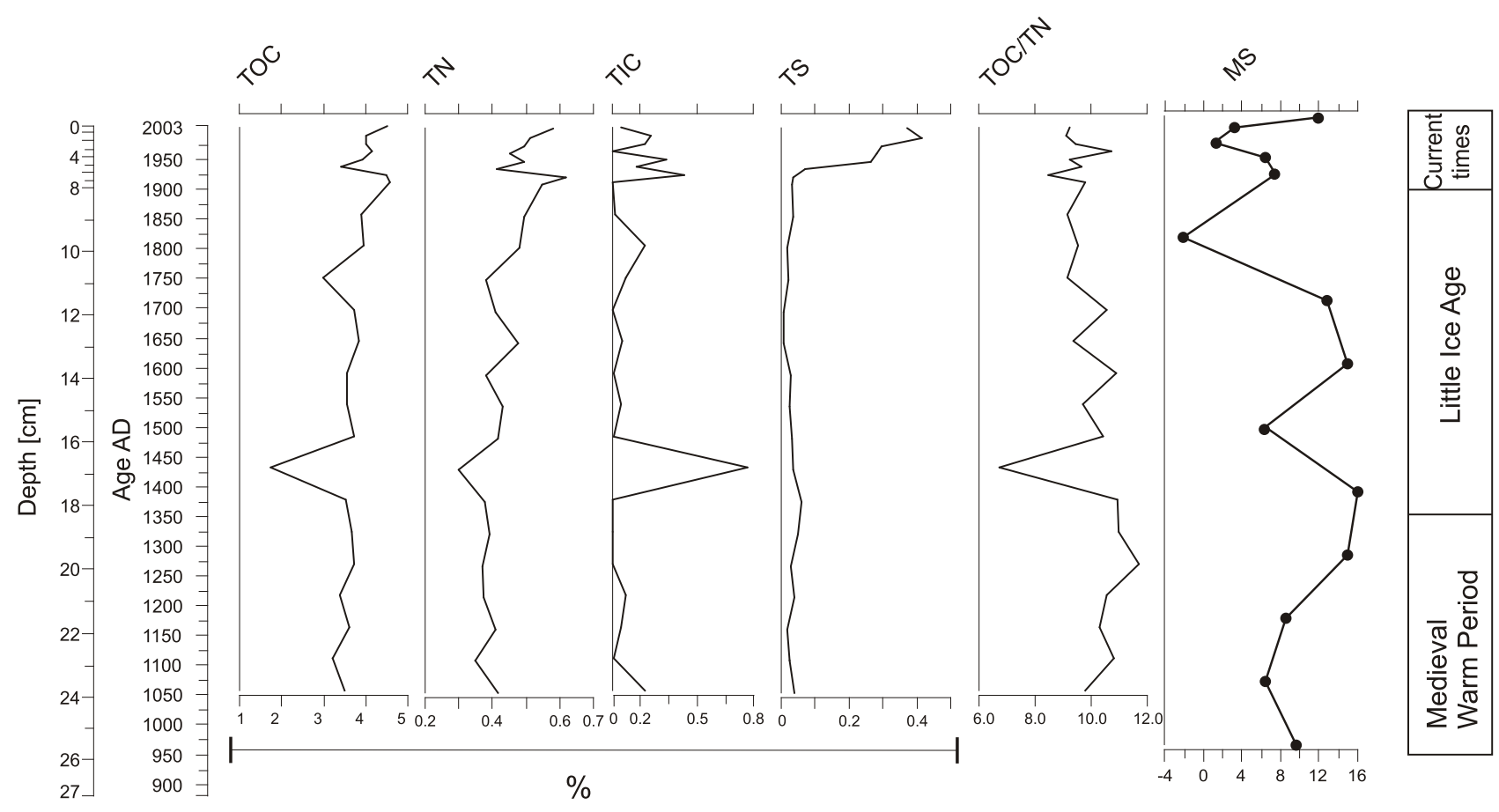

Fig. 4. Chemical composition of a Lake El Sol sediment core from 1050 AD until 1966 AD

TN - total nitrogen, TOC - total organic carbon, TIC - total inorganic carbon, TS - total sulphur; MS - magnetic susceptibility; values in the sediments from 950 until 2003 AD

the core $(27 \mathrm{~cm})$ was dated by means of a conventional radiocarbon method at $1170 \pm 30 \mathrm{BP}$ (Beta-357278), which, after calibration (Calib 7; Stuiver et al., 2005; Reimer et al., 2013), gave an age of $880+10 /-100 \mathrm{AD}$. The age-depth model was built assuming a constant sedimentation date between the $7 \mathrm{~cm}$ horizon dated at $1916 \mathrm{AD}$ by the ${ }^{210} \mathrm{~Pb}$ chronology and the ${ }^{14} \mathrm{C}$ dated horizon at $27 \mathrm{~cm}$.

\section{SUBFOSSIL CLADOCERA AND DIATOM ANALYSIS}

The remains of only four Cladocera species: Daphnia longispina-group (Müller), llyocryptus nevadensis (Cervantez-Martinez, Gutierrez-Aguirre and Elias-Gutierrez), Alona manueli (Sinev and Zawisza) and Chydorus cf. sphaericus (Müller), belonging to three families were recorded in the sediments of Lake El Sol: Daphniidae, Chydoridae, and Macrothricinae. Throughout the entire studied sedimentary sequence, only one planktonic species of the Daphnia longispina-group was present. The Cladocera community was dominated by littoral species. Among them, Ilyocryptus nevadensis and Alona manueli, are endemic and up to now have only been recorded at the Nevado de Toluca crater lake (Cervantez-Martinez et al., 2000; Sinev and Zawisza, 2013). The fourth Cladocera taxa present in the sediments of Lake El Sol was Chydorus cf. sphaericus, which is one of the species most tolerant of unfavourable environmental conditions, especially cold water and nutrient scarcity (Sarmaja-Korjonen, 2004; Bennike et al., 2004).

A total of 23 diatom species were recorded $(>2 \%)$. The species composition was dominated $(>20 \%)$ by tychoplanktonic [Aulacoseira distans (Ehren) Simonsen, Cavinula pseudoscutiformis (Hust.) D. G. Mann and Stickle] and the benthic taxa [Cymbella gracilis (Rabenhorst) Cleve, Navicula NTB1 and Psamothidium levanderi (Hust.) Bukht and Round]. The domi- nance of benthic diatom taxa is related to the high water transparency of the lake that allows photosynthetic activity at the bottom of the water column. Navicula NTB is an unidentified species characteristic of modern lake El Sol that was reported previously by Caballero (1996).

Zone III (880-1340 AD, 18-27 cm): the Cladocera accumulation rate exceeded 60 individuals/year $/ \mathrm{cm}^{2}$. Four Cladocera species were identified. The dominant species was the endemic Alona manueli (mean 88\%). Chydorus cf. shpaericus and the planktonic Daphnia longispina-group were consistently present at mean lower abundances of $<6$ and $<2 \%$, respectively. llyocryptus nevadensis was present at very low relative abundances and was only in the oldest part of this zone. The highest diatom concentration (nearly $8 \times 10^{9}$ valves $/ g$, of dry sediment) was also recorded at this zone. The dominant diatom species were tychoplanktonic Aulacoseira distans (mean 20\%) and Cavinula pseudoscutiformis (mean $30 \%$ ), both acidophilic species. Navicula NTB, possibly endemic for the Nevado de Toluca crater, was present at its lowest relative abundances $(<10 \%)$.

Zone II (1340-1730 AD, 11-18 cm): there was a significant decline in Cladocera accumulation rates (mean 30 individuals $/ \mathrm{cm}^{2} / \mathrm{yr}$ ), particularly of Alona manueli, Ilyocryptus nevadensis, and the Daphnia longispina-group. The most abundant species was Chydorus cf. sphaericus, which reached its highest percentages in the sediment core $(27 \%)$. Diatom concentration also declined $\left(<2 \times 10^{9}\right.$ valves $\left./ \mathrm{g}\right)$ and the relative abundance of both Aulacoseira distans and Cavinula pseudoscutiformis decreased, whereas the epiphytic taxa Cymbella gracilis and Navicula NTB increased.

Zone la (1730-1923 AD, 7-11 cm): the Cladocera accumulation rates increased to 130 individuals $/ \mathrm{cm}^{2} / \mathrm{yr}$. Alona manueli was the predominant species (>90\%), whereas Chydorus cf. sphaericus reached its minimum abundance in the core. In the upper part of this subzone, there was a significant de- 
crease in the Daphnia longispina-group and in Ilyocryptus nevadensis. Diatom concentration decreased $\left(<10^{8}\right.$ valves/g of dry sediment), the most significant decline was in Cavinula psuedoscutiformis, however, relative abundances of Aulacoseira distans and endemic Navicula NTB increased.

Zone Ib (1923-2003 AD, 0-7 cm): the Cladocera accumulation rate reached its highest values in the core (335 ind./ $\mathrm{cm}^{2} / \mathrm{yr}$ ), and Alona manueli was dominant. In the beginning of this phase, llyocryptus nevadensis reappeared. There was an unusual temporary disappearance of the Daphnia longispina group at the beginning of the zone. Diatoms showed their lowest concentration $\left(9 \times 10^{6}\right.$ valves/g of dry sediment) and the Fragilaria sensu lato species complex reached its highest relative abundance.

\section{CHEMICAL COMPOSITION OF SEDIMENTS}

The sediments of Lake El Sol are characterized by relatively low contents of TOC - between 3.0 and $3.5 \%$. There is one outlier at a depth of $17 \mathrm{~cm}$, where the TOC is as low as $1.7 \%$. The TOC shows only minor variations throughout the core, with an overall upward increasing tendency. The exception to this trend corresponds to the beginning of the Little Ice Age (LIA), in the middle part of the 18th century, and in the early decades of the 20th century, when the TOC dropped.

The TN content is strongly positively correlated to the TOC $(r=0.83)$, and thus its temporal variations are similar to the TOC, described above. In the major part of the profile, the ratio of TOC/TN is between 8.5 and 12 , and only at $17 \mathrm{~cm}$ it is lower (ca. 7). Towards the top of the profile, the TOC/TN ratio shows a slightly decreasing trend.

The TIC content is low in the analysed sediments $(<0.2 \%)$. Positive shifts in TIC are seen in a few samples from 1420 to $1530 \mathrm{AD}$ and those from the last century, where the TIC contents are 0.8 and $0.25-0.40 \%$, respectively. The sulphur content of the sediments remained very low $(<0.1 \%)$ prior to the 20 th century. From the onset of the last century until the $1980 \mathrm{~s}$, sulphur input steeply rose to ca $0.4 \%$ and then started to decrease in the uppermost sediments. The palaeolimnological interpretation of chemical data is made with the assumption of good preservation of sedimentary organic matter and only a minor influence of early diagenetic changes (Lami et al., 2000).

\section{RESULTS OF STATISTICAL ANALYSIS}

The statistical properties of the DCA analysis are shown in Table 1 and in Figure 5 we show the axis 1 scores of the samples along the stratigraphic sequence (Fig. 5). DCA results for Cladocera assemblages show that the greatest species turnover happened between 1340 and $1730 \mathrm{AD}$, corresponding to zone II, but before $1340 \mathrm{AD}$ and after $1850 \mathrm{AD}$ Cladocera assemblages were relatively stable. Diatom DCA-axis 1 scores show that the assemblages were quite stable until $1260 \mathrm{AD}$ and since then many high frequency changes occurred with no particular period standing out, but the highest scores are recorded in modern times, since the beginning of the 20th century.

The results of the CA performed with the chemical data (TC, TN, TS, TOC and TIC) are shown in Figure 6. There are no sig-

Ta ble 1

Summary table for DCA results of Cladocera and diatom data for Lake El Sol sediments

\begin{tabular}{|l|c|c|c|c|}
\hline & DCA 1 & DCA 2 & DCA 3 & DCA 4 \\
\hline ues for Cladocera analysis & 0.06458 & 0.03777 & 0.01505 & 0.039106 \\
\hline ues for diatoms analysis & 0.1110 & 0.05071 & 0.01899 & 0.02065 \\
\hline gth for diatoms analysis & 1.2157 & 0.84844 & 0.41745 & 0.54402 \\
\hline
\end{tabular}
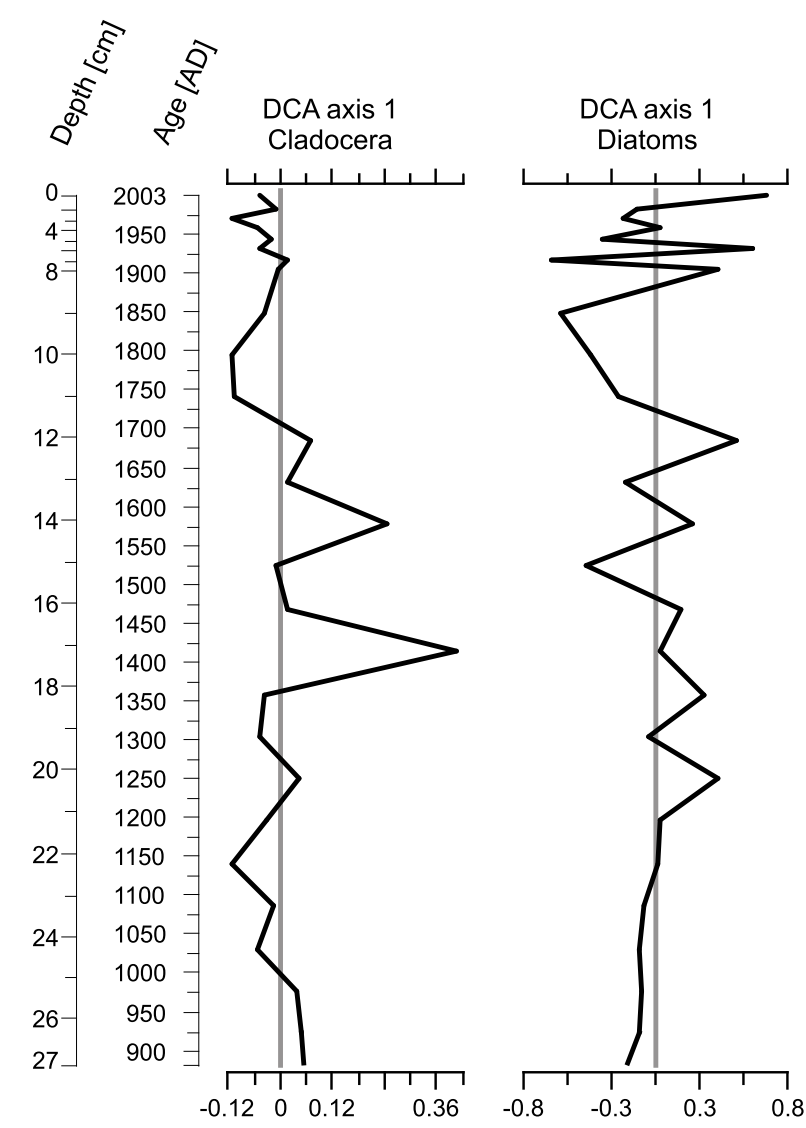

Zones

Fig. 5. Diagram showing the DCA scores for axes 1 of Cladocera and diatom species retrieved from the sediments of Lake EI Sol (Central Mexico) shown on the age and depth scale

nificant changes in chemical composition of the core until 1942 AD, since when sulphur content (TS) became the strongest factor differentiating the samples.

\section{DISCUSSION}

During the last millennium, Lake El Sol experienced some ecological changes (Figs. 3 and 4). The composition of Cladocera, diatoms and the low contents of TOC indicate oligotrophic conditions in the lake. Throughout the core, there some short time periods are represented when the remains of dominant endemic species, Alona manueli, decreased, whereas Chydorus cf. sphaericus increased (e.g., the transition between zones III and II). Ilyocryptus nevadensis, the second 


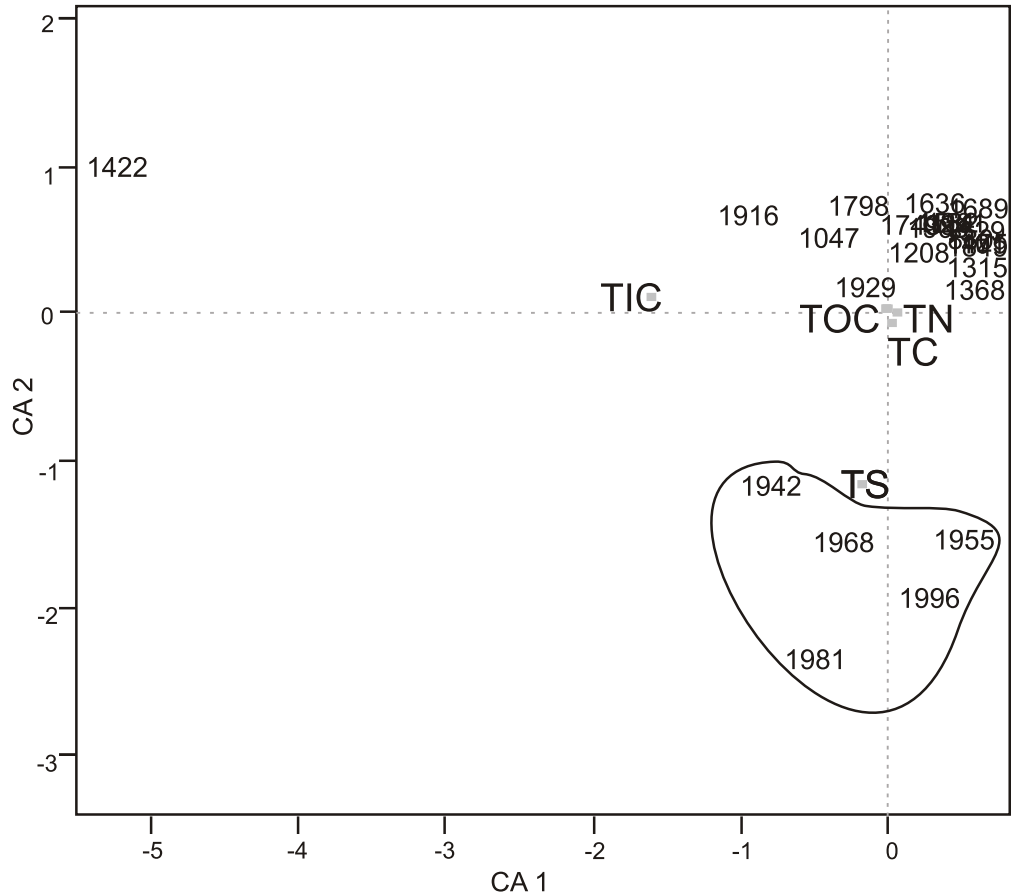

Fig. 6. Correspondence analysis (CA) of sediment chemical composition from Lake EI Sol (1050-2003 AD)

Ellipse corresponds to the samples related with the occurrence of acid rains; for other explanations see text and Figure 5

endemic species in the Nevado de Toluca lakes, was present in low proportion. The habitat of Ilyocryptus nevadensis is quite unusual for this genus for while other species are inhabitants of a muddy substrate, rich in organic material, this species lives on sandy substrates (Cervantes-Martinez et al., 2000). Alona manueli inhabits the littoral zone and lives in association with plants on sandy sediment. As suggested by previous studies (Zawisza et al., 2012; Sinev and Zawisza, 2013; Cuna et al., 2014), both endemic species prefer benthic habitats and are tolerant to low nutrient concentrations and low $\mathrm{pH}$ values. However, the ecology of these species is still not well-known.

The oldest studied sediment from Lake El Sol (Zone III, 880-1340 AD) was deposited during the Medieval Climate Anomaly (MCA; 800-1350 AD) (Haug et al., 2003; Verschuren and Charman, 2008). Archaeologically, this zone corresponds to the first half of the Mesoamerican Postclassic period (950-1521 AD). The Cladocera composition, especially the highest percentages in the sediment core of the Daphnia longispina-group, suggests that during the MCA, the lake was deeper. The dominance of the plant-associated species, Alona manueli (>88\%) indicates the that littoral zone was colonised by macrophytes. These features created favourable conditions for zooplankton to develop. The higher water level in Lake El Sol was consistent with the dominance of tychoplanktonic diatoms (Aulacoseira distans and Cavinula psuedoscutiformis) that prefer more dilute waters with lower $\mathrm{pH}$ values. The high values of MS at the end of the MCA point to increased atmospheric precipitation as the main cause of the lake level increase (Cuna et al., 2014). Moreover, the precipitation-controlled water level explains the low trophic state and the low $\mathrm{pH}$ of the lake waters, similar to Lake La Luna (Cuna et al., 2014). However, the higher contribution of macrophytes in Lake $\mathrm{El}$ Sol is shown by the higher TOC/TN ratio. The link between the enhanced precipitation and the increase in MS is intensified erosion in the catchment during a more humid climate. The MS is likely to increase owing to a de- crease in TOC. However, in the profile analysed such an interpretation seems unsuitable because the MS increase commenced considerably earlier than the drop in TOC (ca. 1425-1450 AD).

At the second half of the 14th century (beginning of zone II), appreciable changes in Lake El Sol took place. The frequency of macrophyte sediment-associated Cladocera (Alona manueli and llyocryptus nevadensis) and planktonic species (the Daphnia longispina-group) significantly decreased, whereas the frequency of the very tolerant Chydorus cf. sphaericus increased (Fig. 3). At the same time significant changes occurred in diatom communities, with a decline in tychoplanktonic taxa (Aulacoseira distans and Cavinula psuedoscutiformis) and an increase in epiphytic ones (Cymbella gracilis and Navicula NTB). The decrease in planktonic species of Cladocera and tychoplanktonic diatoms indicates a decrease in rainfall and, in consequence, a reduction in lake level. Those changes indicate unfavourable environmental conditions, such as lower lake level and temperature. Those changes could have resulted from cooling during the LIA (1350-1850) (Lozano-Garcia et al., 2007; Metcalfe and Davies, 2007; Cuna et al., 2014). The LIA in Central Mexico was characterized by lower air temperatures, lower precipitation and longer and colder winters (Metcalfe and Davies, 2007). Lower MS values indicated a decline in atmospheric precipitation in the surroundings of Lake EI Sol, and the lowering of the lake water level was corroborated by a decrease in the frequency of planktonic and plant- and sediment-associated Cladocera species. Climatic conditions (long winter, cold and dry) favoured increasing numbers of the tolerant species Chydorus cf. sphaericus. A cold climate is also suggested by Cladocera DCA analysis where the highest value of axis 1, correlated with temperature, is recorded in zone II. During the LIA, shares of Alona manueli and of the Daphnia longispina-group decreased, suggesting lower lake productivity at the time. The deterioration of the climate in the early part of the LIA (1400-1450 AD) was recorded by the lower values of TOC and TOC/TN (ca. 7). This interpretation would mean that the climate cooling resulted in more pronounced oligotrophy of the lake and in a more important role of phytoplankton in producing sedimentary organic matter. The role of higher plants (macrophytes) was reduced. The environmental changes during the early LIA found in Lake El Sol were similar to those observed in Lake La Luna (Zawisza et al., 2012; Cuna et al., 2014).

In the second half of the 15th century, geochemical parameters of the sediments became similar to those during the pre-LIA period. Carbonate-free sediments with a higher TOC/N ratio $(\sim 10-13)$ indicate diminished contribution of phytoplankton (and possibly a higher abundance of macrophytes) in lake bioproducivity (Meyers and Teranes, 2001). In the last decades of the 16th century, the climate became slightly more humid, as shown by the higher values of MS.

In the 18th century, the plant- and sediment-associated Cladocera (particularly Alona manueli and Ilyocryptus nevadensis) became very abundant. In subzone la, the relative abundances of Chydorus cf. sphaericus reached its minimum. The increasing abundance of Cladocera and the disappearance of Chydorus cf. sphaericus remains might indicate an improvement in climatic conditions and edaphic processes after the LIA. In this subzone the highest values of the tychoplanktonic $A$. distans could indicate a return to previous water 
levels in the lake. Nowadays this species is abundant in modern alpine lakes. Increased relative abundance of this species could indicate an increase in the water level, or alternatively can be thought to reflect the presence of a seasonal (winter) ice cover on the lake (Wolfe and Härtling, 1996).

The frequency of Cladocera individuals significantly increased since the beginning of the 19th century. The magnetic susceptibility values were low, indicating that zone la was a relatively dry period. According to Iwasniszewski (1986), during the 19th century, local indigenous people climbed to the Nevado de Toluca crater and deposited ceremonial offerings in the lakes to request rain. Between the mid-18th and the early decades of the 20th century, there was a clear decrease in precipitation. At the same time, biological productivity in Lake El Sol increased, as shown by the increasing TOC values. In addition to this increase, the organic matter was primarily produced by phytoplankton, as shown by the TOC/N ratio between 9 and 10 .

At the beginning of subzone $\mathrm{lb}$, there was a temporary absence of Daphnia longispina-group remains in the sediments. This sudden disappearance of Daphnia remains may be correlated with the first introduction of fish to the lake. According to historical data, during the first part of the 20th century there were several attempts to introduce fish to Lake El Sol (Dimas-Flores et al., 2008). Currently, a small stunted population of trout exists in this lake.

During most of the 20th century, the lake was appreciably unstable. First, there was a drop in bioproductivity followed by an increase in biomass production. This change was probably caused by increased primary production in the lake. The higher contents of TIC might have resulted from a slight increase in $\mathrm{pH}$. Increased $\mathrm{pH}$ is indicated by an increasing share of diatoms, especially species whose optimum $\mathrm{pH}$ is close to 7 such as Fragilaria spp. (Battarbee et al., 2011; http://craticula.ncl.ac.uk/Eddi). This trend was also observed in the Lake La Luna (Cuna et al., 2014), and possibly indicates the beginning of the modern warming period (Pienitz et al., 2006). However, it is important to mention that this trend may also be a consequence of fish introduction which increases the trophic status of the lake. A high concentration of sulphur is present in the sediments from this time (Figs. 4 and 6), which could be linked with atmospheric transport related to anthropogenic activity (Lami et al., 2000; Pienitz et al., 2006) and/or the deterioration of redox conditions in the lake (Doran et al., 2004). On the other hand, the increase in TIC accompanying the enhanced $S$ contents argues against a significant $\mathrm{pH}$ drop in lake waters. Palaeolimnological and historical data indicate that higher concentration of sulphur in the sediments might be related to anthropogenic activity. CA analysis supports also the occurrence of acid rain in the second part of XX century (1942-1996) which can be correlated with the industrial development of Mexico City. The time from 1940 till 1980 was the period of the most important industrial development at the area (Sanchez-Almanza, 2012) and from the end of the 1980s, several environmental measures were implemented to control the emissions of atmospheric pollutants from industry and the transport services in the metropolitan zone of Mexico City.

During recent decades, the conditions of Lake El Sol have been different from the major part of the last millennium. Besides the trends presented in this paper, Cuna (2014) also doc- umented a significant increase in algal remnants which may indicate a trend towards nutrient enrichment in the lake. This increase might be the result of fish introduction, which affected the control that zooplankton exert on algal biomass (top-down control), which is typical of naturally fishless lakes (Jeppesen et al., 1998).

\section{CONCLUSIONS}

The results of subfossil Cladocera and diatom analysis from the core sediments of Lake El Sol showed that during the last 1000 years, the lake was relatively stable with respect to environmental conditions. The changes in the lake were mainly controlled by natural (climatic) factors, with the exception of the 20th century, during which some anthropogenic pressure affected the lake system.

Ancient periods of human activity in both Nevado de Toluca lakes were suggested by Junco (2010) and Luna (2000) and might have influenced the trophic status. However, our results do not support those suggestions. We were not able to distinguish human impact on the Lake El Sol ecosystem prior to the 20th century. The results obtained suggest rather that earlier human activity around the lake was very limited and probably was only occasional (ceremonial and ritual celebrations). Within the last millennium, we identified only one period when human impact was important, the introduction of fish in the beginning of 20 th century that is clearly reflected in the subfossil cladoceran and diatom communities. In addition, an increased sulphur content provides evidence for deterioration of red-ox conditions.

During the last millennium, the ecosystem of Lake El Sol responded to changes in temperature and precipitation, which were expressed by changes in the Cladocera and diatom communities and in the bulk geochemical parameters. In general, ecological changes reflected in the sediments of Lake El Sol followed local climatic changes that occurred in Central Mexico (Metcalfe and Davies, 2007; Cuna et al., 2014). These results provide new data that allowed us to better understand these climatic changes. The data presented, especially the results of the subfossil Cladocera analysis, provide supplementation of the current results, and they reduce the existing knowledge gap regarding zooplankton communities in high altitude lakes.

Acknowledgements. The study was funded by the Polish Ministry of Science (Grant NCN 2012/05/B/ST10/00469); the Universidad Nacional Autónoma de México UNAM-PINCC "Los lagos del Nevado de Toluca, México, centinelas para la detección y análisis del cambio global" and UNAM-DGAPA project IN105009. This research was made possible by the support of the Institute of Geological Sciences of the Polish Academy of Sciences (ING PAN) and the Institute of Geography and Spatial Organization (IGiPZ PAN) of the Polish Academy of Sciences. Technical support was provided by S. Sosa, A. Rodríguez and L.H. Perez-Bernal. Access to the lakes was possible thanks to the Comisión Estatal de Parque Naturales y de la Funa (CEPANAF), Secretaría de Ecología, Estado de México. The authors thank the Reviewer S. Davies and anonymous Reviewer as well as journal co-editor W. Granoszewski for their helpful comments and suggestions which improved the manuscript. 


\section{REFERENCES}

Alcocer, J., Oseguera, L.A., Escobar, E., Peralta, L., Lugo, A., 2004. Phytoplankton biomass and water chemistry in two high mountains, tropical lakes in central Mexico. Arctic, Antarctic and Alpine Research, 36: 342-346.

Arce, J.L., Macias, J.L., Vazquez-Selem, L., 2003. The 10.5 ka Plinian eruption of Nevado de Toluca volcano, Mexico: stratigraphy and hazard implications. GSA Bulletin, 115: 230-248.

Armienta, M.A., De la Cruz-Reyna, S., Macías, J.L., 2000. Chemical characters of the crater lakes of Popocatepetl, el Chichon, and Nevado de Toluca volcanoes, Mexico. Journal of Volcanology and Geothermal Research, 97: 105-125.

Battarbee, R., 1986. Diatom analysis. In: Handbook of Holocene Palaeoecology and Palaeohydrology (ed. B.E. Berglund): 527-570. John Wiley and Sons Ltd.

Battarbee, R.W., Grytnes, J.A., Thompson, R., Appleby, P.G. Catalan, J., Korhola, A., Birks, H.J.B., Heegaard, E., Lami, A., 2002. Comparing palaeolimnological and instrumental evidence of climate change for remote mountain lakes over the last 200 years. Journal of Paleolimnology, 28: 161-179.

Battarbee, R., Simpson, G., Bennion H., Curtis, C., 2011. A reference typology of low alkalinity lakes in the UK based on pre-acidification diatom assemblages from lake sediment cores. Journal of Paleolimnology, 45: 489-505.

Bennike, O., Sarmaja-Korjonen, K., Seppanen, A., 2004. Reinvestigation of the classic late-glacial Bølling Sø sequence, Denmark: chronology, macrofossils, cladocera and chydorid ephippia. Journal of Quaternary Sciences, 19: 465-478.

Bigler, C., Lotter, A.F., Hausmann, S., Blass, A., Ohlendorf, C., Strum, M., 2007. Quantifying human induced eutrophication in Swiss mountain lakes since AD 1800 using diatoms. Holocene, 17: 1141-1154.

Bloomfield, K., Valastro, S., 1979. Late Pleistocene eruptive history of the Nevado de Toluca volcano central Mexico. GSA Bulletin, 85: 901-906.

Caballero, M., 1996. The diatom flora of two acid lakes in Central Mexico. Diatom Research, 11: 227-240.

Cervantes-Martinez, A., Gutierrez-Aguirre, M., Elias-Gutierrez, M., 2000. Description of Iliocryptus nevadensis (Branchiopoda, Anomopoda), a new species from high altitude rater lake in the volcano Nevado de Toluca, Mexico. Crustaceana, 354: 311-321.

Coronel, J.S., Declerck, S., Brendonck, B., 2007. High-altitude peatland temporary pools in Bolivia house a high Cladocera diversity. Wetlands, 27: 1166-1174.

Cuna, E., Zawisza, E., Caballero, M., Ruiz-Fernandez, A.C., Lozano-Garcia, S., Alcocer, J., 2014. Environmental impacts of Little Ice Age cooling in central Mexico recorded in sediments of a tropical alpine lake. Journal of Paleolimnology, 51: 1-14.

Dimas-Flores, N., 2005. Dinamica y estructura del zooplankton de dos lagos de alta Montana, Mexico. Tesis de maestria en ciencias del mar y limnologia. Posgrado en Ciencias del Mar y Limnologia, UNAM, Mexico: 1-132.

Dimas-Flores, N., Alcocer, J., Ciros-Pérez, J., 2008. The structure of the zooplankton assemblages from two neighboring tropical high mountain lakes. Journal of Freshwater Ecology, 23: 21-31.

Doran, P.T., Priscu, J.C., Lyons, W.B., Powell, R.D., Andersen, D.T., Poreda, R.J., 2004. Paleolimnology of extreme cold terrestrial and extraterrestrial environments. In: Long-term Environmental Change in Arctic and Antarctic Lakes (ed. R. Pienttz): 475-507. Kluwer Academic Publishers.

Elias-Gutierrez, M., Cirioz-Perez, J., Guterez-Aguirre, M., Cervantez-Martinez, A., 1997. A checklist of the littoral Cladocerans from Mexico, with description of five taxa recently recorded from the Neovolcanic Province. Hydrobiologia, 360: 63-73.

Elias-Gutierrez, M., Suarez-Morales, E., Gutierrez-Aguirre, M.A., Silva-Briano, M., Grnados-Ramirez, J.G., Garfias-Espejo, T., 2008. Cladocera y Copepoda de las aguas continentales de Mexico. Guia ilustrada. Unam, Ecosur, Semarnat-Conacyt, Conabio, México, D.F.

Frey, D.G., 1986. Cladocera analysis. In: Handbook of Holocene Palaeoecology and Palaeohydrology (ed. B.E. Berglund): 667-692. John Wiley and Sons Ltd.
García-Palomo, A., Macías, J.L., Arce, J.L., Capra, L., Garduńo, V.H., Espíndola, H.M., 2002. Geology of Nevado de Toluca Volcano and surrounding areas, central Mexico. GSA Map and Chart Series, MCH099, 14

Gauch, H.G., 1982. Multivariate Analysis in Community Ecology. Cambridge University Press, Cambridge, UK.

Gonzalez, R., 1984. Estudio de la productividad primaria de lago de Sol en el volcan Nevado de Toluca Edo de México. Tesis Licenciatura. Facultad de Ciencas, UNAM, México.

Grimm, E.C., 1987. CONISS: a Fortran 77 program for stratigraphically constrained luster analysis by the method of incremental sum of squares. Computers and Geosciences, 13: 3-35.

Haug, G.H., Gunther, D., Peterson, L.C., Sigman, D.M., Hughen, K.A., Aeschlimann, B., 2003. Climate and the collapse of the Maya civilization. Science, 299: 1731-1735.

Hofmann, W., 2000. Response of the chydorid faunas to rapid climatic changes in four alpine lakes at different altitudes. Palaeogeography, Palaeoclimatology, Palaeoecology, 159: 281-292.

Iglesias, C., Goyenola, G., Mazzeo, N., Meerhoff, M., Rodo, E., Jeppesen, E., 2007. Horizontal dynamics of zooplankton in subtropical Lake Blanca (Uruguay) hosting multiple zooplankton predators and aquatic plant refuges. Hydrobiologia, 584: 179-189.

Iwasniszewski, S., 1986. La arqueología de alta montaña en México y su estado actual. Estudios de cultura Nahuatl. Universidad Nacional Autónoma de México, Instituto de Investigaciones Históricas Publisher, Mexico.

Jeppesen, E., Søndergaard, M., Jensen, J.P., Kanstrup, E. Petersen, B., 1998. Macrophytes and turbidity in brackish lakes with special emphasis on the role of top-down control. Ecological Studies, 131: 369-377.

Juggins, S., 2005. New features in C2 version 1.4. Newcastle, University of Newcastle.

Juggins, S., 2007. User guide C2 Software for Ecological and Palaeoecological Data Analysis and Visualisation User Guide Version 1.5. Newcastle, University of Newcastle.

Junco, R., 2010. Lagunas del Nevado de Toluca, estado de México, devoción prehispánica. Arqueología Mexicana, 18: 43-47.

Kamenik, C., Szeroczyńska, K., Schmidt, R., 2007. Relationships among recent Alpine Cladocera remains and their environment: implications for climate - change studies. Hydrobiologia, 594: 33-46.

Kattel, G., 2010. Biogeography and taxonomy of New Zealand Cladocera (Anomopoda, Chydoridae): a review. Journal of the Royal Society of New Zealand, 40: 209-224.

Koining, K.A., Kamenik, C., Schmidt, R., Agusti-Panareda, A. Appleby, P., Lami, A., Prazakova, M., Rose, N., Schnell, Ø.A., Tessadri, R., Thompson, R., Psenner, R., 2002. Environmental changes in an alpine lake (Gossenkolesee, Austria) over the last two centuries - the influence of air temperature on biological parameters. Journal of Paleolimnology, 28: 147-160.

Kotov, A.A., Sinev, A.Y., Berrios, V.B., 2010. The Cladocera (Crustacea: Branchiopoda) of six high altitude water bodies in the North Chilean Andes, with discussion of Andean endemism. Zootaxa, 2430: 1-66.

Krammer, K., Lange-Bertalot, H., 1986-1991. Süßwasserflora von Mitteleuropa. 2 (Teil 1-4). Stuttgart-Jena: VEB Gustav Fischer Germany.

Krammer, K., Lange-Bertalot, H., 1991. Bacillariophyceae. 4. Teil: Achnanthaceae. Kritische Ergänzungen zu Navicula (Lineolatae) und Gomphonema. Gesamtliteraturverzeichnis. Teil 1-4. In: Süßwasserflora von Mitteleuropa, 2 (4) (eds. H. Ettl, J. Gerloff, H. Heynig and D. Mollenhauer): G. Fischer, Stuttgart and Jena.

Krishnaswami, S., Lal, D., Martin, J.M., Meybeck, M., 1971. Geochronology of lake sediments. Earth and Planetary Science Letters, 11: 407-414

Lami, A., Guilizzoni, P., Marchetto, A., 2000. High resolution analysis of fossil pigments, carbon, nitrogen and sulphur in the sediment of eight European Alpine lakes: the MOLAR project. Journal of Limnology, 59: 15-28. 
Lozano-Garcia, S., Caballero, M., Ortega, B., Rodriguez, A., Sosa, S., 2007. Tracing the effects of the Little Ice Age in the tropical lowlands of eastern Mesoamerica. PNAS, 104: 16200-16203.

Luna, E.P., 2000. El Nevado de Toluca sitio de veneración prehispánica. Arqueología Mexicana, Serie Tiempo Mesoamericano, 1: 47-49.

Macías, J.L., 2005. Geología e historia eruptiva de algunos de los grandes volcanes activos de México. Boletín de la Sociedad Geológica Mexicana Volumen Comenmorativo del Centenario Temas selectos de la Geología Mexicana, 17: 379-424.

Macías, J.L., Arce, J.L., Layer, P.W., Saucedo, R., Mora, J.C., 1997. Eruptive history of the Tacana Volcanic Complex. In: Active Volcanoes of Chiapas (Mexico): El Chichon and Tacana (eds. T. Scolamacchia and J.L. Macias): 115-138. Springer-Verlag, Berlin, Heidelberg.

McCormack, J.E., Huang, H., Knowles, L.L., 2009. Sky islands. In: Encyclopedia of Islands (eds. R.G. Gillespie and D. Clague): 839-843. University of California Press, Berkeley.

Metcalfe, S., Davies, S., 2007. Deciphering recent climate change in central Mexican lake recordes. Climate Change, 83: 169-186.

Meyers, P.A., Teranes, J.L., 2001. Sediment organic matter. In: Tracking Environmental Change Using Lake Sediments, 2: Physical and Geochemical Methods (eds. W.M. Last and J.P. Smol): 239-269. Kluwer Academic Publishers, Dordrecht.

Oksanen, J., Blanchet, F.G., Kindt, R., Legendre, P., Minchin, P.R., O'Hara, R.B., Simpsom, G.L., Solymos, P., Stevens, H., Wagner, H., 2012. CRAN - Package vegan: Community Ecology Package. R package version 2.0-4

Pienitz, R., Roberge, K., Vincent, W.F., 2006. Three hundred years of human - induced change in an urban lake: paleolimnological analysis of Lac Saint-Augustin, Quebec City, Canada. Canadian Journal of Botany, 84: 303-320.

Reimer, P.J., Bard, E., Bayliss, A., Beck, J.W., Blackwell, P.G., Bronk Ramsey, C., Buck, C.E., Cheng, H., Edwards, R.L., Friedrich, M., Grootes, P.M., Guilderson, T.P., Haflidason, H., Hajdas, I., Hatté, C., Heaton, T.J., Hoffmann, D.L., Hogg, A.G., Hughen, K.A., Kaiser, K.F., Kromer, B., Manning, S.W., Niu, M., Reimer, R.W., Richards, D.A., Scott, E.M., Southon, J.R., Staff, R.A., Turney, C.S.M., van der Plicht, J., 2013. IntCal13 and Marine13 radiocarbon age calibration curves 0-50,000 years cal BP. Radiocarbon, 55: 1869-1887.

Sanchez-Almanza, A., 2012. La evolución de la Ciudad de Mexico factores para el desarrollo social. Informe del Estado de desarrollo social en el Distrito Federal, México, D.F.
Sanchez-Cabeza, J.A., Ruiz-Fernández, A.C., 2012. ${ }^{210} \mathrm{~Pb}$ sediment radiochronology: an integrated formulation and classification of dating models. Geochimica et Cosmochimica Acta, 82: 183-200.

Sarmaja-Korjonen, K., 2004. Chydorid ephippia as indicators of past environmental changes - a new method. Hydrobiologia, 526: 129-136.

Serafim, Jr., Lansac-Tôha, F.A., Paggi, J.C., Velho, L.F., Robertson, B., 2003. Cladocera fauna composition in a river-lagoon system of the upper Paraná River floodplain, with a new record for Brazil. Brazilian Journal of Biology, 63: 349-356.

Sinev, A.Y., Zawisza, E., 2013. Comments on cladocerans of crater lakes of the Nevado de Toluca Volcano (Central Mexico), with the description of a new species, Alona manueli sp. Zootaxa, 3647: 390-400.

Stuiver, M., Reimer, P.J., Reimer, R.W., 2005. Radiocarbon Calibration Program CALIB Rev 5.0.1

Szeroczyńska, K., Sarmaja-Korjonen, K., 2007. Atlas of Subfossil Cladocera from Central and Northern Europe. Friends of the Lower Vistula Society.

Szeroczyńska, K., Zawisza, E., Wojewódka, M., 2015. Initial time of two high altitude crater lakes (Nevado de Toluca, Central Mexico) recorded in subfossil Cladocera. Studia Quaternaria, 32: 109-116.

Team RDC, 2009. R: A language and environment for statistical computing. R Foundation for Statistical Computing, Vienna, Austria.

Wolfe, A.P., Härtling, J.W., 1996. The late Quaternary development of three ancient tarns on southwestern Cumberland Peninsula, Baffin Island, Artic Canada: paleolimnological evidence from diatoms and sediment chemistry. Journal of Paleolimnology, 15: 1-18.

Verschuren, D., Charman, D.J., 2008. Latitudinal linkages in late Holocene moisture-balance variation. In: Natural Climate Variability and Global Warming (eds. R.W. Battarbee and H.A. Binney): 189-232. The Atrium, Southern Gate, Chichester, Wiley-Blackwell.

Voigt, R., 2006. Settlement history as reflection of climate change: the case study of Lake Jues (Harz Mountains, Germany). Geographical Analysis, 88A: 97-105.

Zawisza, E., Caballero, M., Ruiz-Fernandez, C., 2012. Ecological changes recorded in the sediments of high altitude tropical lake Lago de la Luna (central Mexico) based on subfossil Cladocera analysis. Studia Quaternaria, 29: 14-21. 